\title{
The Effect of Demographic Factors on The Investment Decision in Beef Cattle Farming Using Profit Sharing Systems in West Sumatera
}

\section{Pengaruh Faktor Demografi Terhadap Keputusan Investasi Pada Usaha Peternakan Sapi dengan Sistem Seduaan di Sumatera Barat}

\author{
I. Iskandar dan Fitrimawati* \\ Faculty of Animal Science, Universitas Andalas, Padang, Indonesia, 25163 \\ *E-mail: fitrimawati@yahoo.com
}

(Diterima: 18 Maret 2019; Disetujui: 10 Mei 2019)

\begin{abstract}
The aim of this study was analyzing the demographic profile and its influence on investor's investment decisions on the business of people's cattle farm through benefit sharing system. The research was the survey method and data obtained from questionnaires by investors in cattle farming through benefit sharing system in West Sumatera. The method of data analysis was a multiple regression method with a variable dummy. The results of the study showed that the investors were from different age and sex. There were respondents who were young to old and the total numbers of woman and man were almost the same. Most of them are an entrepreneur and there are only a few of them who are civil servants or private sector worker. Their education starts from elementary school to college, but most of them are elementary school graduates. Education is crucial in investment decisions rather than gender, age, and occupation. These categories do not significantly affect investment decisions in benefit sharing system of beef farmers in West Sumatera.
\end{abstract}

Keywords: benefit sharing, cattle, demography, investment, profile

\section{ABSTRAK}

Penelitian ini bertujuan untuk menganalisis profil demografi dan pengaruhnya terhadap keputusan investasi penanam modal pada usaha sapi rakyat melalui sistem seduaan. Metode penelitian yang digunakan adalah metode survei menggunakan kuesioner terhadap penanam modal dalam usaha sapi seduaan di Sumatera Barat. Data yang digunakan adalah data kualitatif dan kuantitatif yang dianalisis menggunakan teknik pengolahan data secara deskriptif kuantitatif. Untuk menganalisis pengaruh profil demografi terhadap keputusan investasi penanam modal pada usaha sapi rakyat melalui sistem seduaan maka digunakan metode regresi berganda dengan dummy variabel. Hasil penelitian didapatkan bahwa penanam modal pada sapi seduaan ada yang berumur muda sampai tua dan demikian juga dalam hal jenis kelamin. Jumlah perempuan dan laki-laki hampir sama banyaknya. Pekerjaannya mayoritas wirausaha dan ada beberapa saja yang pegawai negeri atau swasta. Pendidikan mereka mulai dari sekolah dasar sampai perguruan tinggi namun sekolah dasar sedikit lebih banyak. Pendidikan sangat menentukan dalam keputusan investasi sedang jenis kelamin, umur dan pekerjaan tidak berpengaruh nyata terhadap keputusan investasi dalam usaha sapi seduaan.

Kata kunci: demografi, investasi, profil, sapi, seduaan

\section{INTRODUCTION}

Animal husbandry development is a very important part of national development in fulfilling the food needs of Indonesian people. The needs of the Indonesian people for animal husbandry products are very high (Fuah et al., 2015). Indonesia is classified as the fourth most populous country in the world. Population growth increased by 
1.5 percent every year and also increased economic growth. Therefore, it is estimated that consumption of livestock products as a source of animal protein will also increase (Fatmawati et al., 2016). It means that the development of animal husbandry must be increased to the maximum. However, the condition of animal husbandry in Indonesia is very alarming when it is viewed in terms of animal husbandry production and population.

In order to realize the acceleration of self-sufficiency in beef, the strategy for developing beef cattle is directed at upstream structures, namely breeding. The government has tried to increase the financing in the animal husbandry subsector, especially cattle farm. Among other things, by increasing the budget allocation for cattle farms. Since 2017 the Indonesia Government State Budget allocation has been focused on Special Efforts of Mandatory Cattle Breeding (in Indonesia: UPSUS SIWAB). It is expected to increase the productivity of local cattle (Said, 2017). Meanwhile, in West Sumatera, the efforts to increase the cattle population at the level of folk farmers have occurred since ancient times until now. The Minangkabau community that based on custom and culture has contributed to the development of animal husbandry especially cattle farms. Minangkabau people who have high financial strength will share with relatives and villagers who are poor. One of the ways they do is to invest money to buy cattle and it is kept by their less fortunate relatives. If the cattle give birth, the two parties will get the same outcome. In Minangkabau, raising cattle with a profit-sharing system is called a cattle-breeding business with seduaan system. It is applied based on the basis of the social capital that they practice.

The investors with farmers do not make any contracts or agreements in the face of the risks that occur. In the case, animal husbandry agribusiness is a high-risk business, especially the cattle business. Cattle are living things that have a risk of death anytime. They are also the high valuable assets that can increase the risk of being lost sometimes. However, based on the preliminary survey research, investors accept any risks that occur without risk to farmers. All of that is only driven by the desire to share and a sense of social responsibility to the lives of their relatives to be better. Therefore, the author's thought about what the investor's demographic profile in the cattle farm agribusiness like, especially seduaan business. It is very important to know because according to Cahyadi (2006), investment is related to demographic factors such as religion, age, gender, marital status, education, occupation, and income. Therefore, the authors are interested in analyzing the relationship between demographic factors and investment decisions in the business of beef cattle farmers through the benefit-sharing system.

\section{METHOD}

This study used an exploratory method. The aim of using this method is to gain a deeper understanding of the profile of the investor's investment decisions on people's cattle agribusiness through seduaan system (Kuncoro, 2003). This research was done in Minangkabau West Sumatera. The population in the study was an investment in cattle farming business with seduaan system. There is no record of population numbers. The research method was a non-probability sampling method that is purposive sampling method. The selection of respondents was based on regions where many people invest in cattle farming businesses with the seduaan system. The number of research respondents is 58 people.

This research used the data on investor's investment decisions including the amount of investment, investment allocation, and investor demographic profile. In this study, the data obtained from the research results were processed based on the following procedures, namely editing, data coding, data tabulation, and data analysis. The data analysis technique used was descriptive quantitative analysis and 
multiple regression with dummy variables.

Multiple regression methods with dummy variables were used to analyze the influence of investor demographic profiles on investment decisions. In this model, the dependent variable is affected by both the independent variables quantitative and qualitative variables. The investment decision as a dependent variable that is proxied from the amount of money invested in cattle farming business with the seduaan system. The quantitative variables used in this model are age and education which are proxied from the length of study. The qualitative variable is quantified which is known as the dummy variable which gave the values 1 and 0 . Value 1 indicates the existence, while the value 0 indicates the absence of these quality traits. For example for gender variables, value 1 is used for male, then the value of 0 indicates female. Occupation variable was also a dummy variable so the value of 1 for government employees while 0 for nongovernment employees.

The regression equation model is:

$$
\begin{aligned}
\mathrm{Y}= & \alpha_{0}+\alpha_{1} \text { Xage }+\alpha_{2} \text { Xedu }+\alpha_{3} \text { Djob }+\alpha_{4} \\
& \text { Dgender }+\epsilon
\end{aligned}
$$

Where:

$$
\begin{array}{ll}
\mathrm{Y} & =\text { Investment decision } \\
\text { Xage } & =\text { Age } \\
\text { Xedu } & =\text { Education } \\
\text { Djob } & =\text { Occupation } \\
\text { Dgender } & =\text { Gender }
\end{array}
$$

A regression model with a dummy variable must fulfill two tests, namely statistical test, and econometric test. Statistical tests were performed on the t-statistic values (significance test of individual parameters) and F-statistic tests as well as the determination (R-square) test. The $\mathrm{t}$ statistical test shows how far the influence of one independent variable individually explains the variation of the dependent variable. The F statistical test shows whether all independent variables have a joint influence on the dependent variable. Econometric testing is also known as the classic assumption test, a requirement that must be fulfilled in multiple linear regression analysis based on Ordinary Least Square. The classic assumption test used is multicollinearity test, heteroscedasticity test, normality test, autocorrelation test, and linearity test.

\section{RESULT AND DISCUSSION}

Based on the results of the study, the majority of the people who are interested in investing in the cattle farm agribusiness sector withe the seduaan system are male (Tabel 1).

In Table 1 It is seen that investors are male as many as 58.6 percent and women 41.4 percent. The highest number of investors in the cattle farm business is men and also women. The number of men and women is not much different. It means that in West Sumatra, women are also interested to invest in smallholder cattle farm businesses with the seduaan system, even though the amount of men was still higher than women. It is because men are more willing to take risks in investing. This is as stated by Barber and Odean (2001) which explains that men are more courageous about the risks that will be faced compared to women. It is because the level of male self-confidence is higher than women. The same results were also obtained by Tallo et al. (2015), he found a significant relationship between sex and risk profile where the results of male and female respondents clearly showed that men were more willing to take risks in investing or risk moderate at 0.714 or $(71.45 \%)$. and tends towards risk aggressive. According to Fisher (2010), it happens because men are more confident to have a high return. Meanwhile, women prefer safe and secure paths due to the lower level of confidence of women than men, which is equal to 0.622 or $(62.2 \%)$ respondents tend to be risk conservative. It is also in line with Edward and Prakash research (2007). In short, by seeing the percentage of women who are not much different from the percentage of men, it can be interpreted 
Table 1. Profile of Demographic Investors in Cattle Farming Business with The Seduaan System

\begin{tabular}{llcc}
\hline Profile of Demographics & Frequency (People) & Percent (\%) \\
\hline Gender & Men & 34 & 58.6 \\
& Women & 24 & 41.4 \\
& $20-30$ & 8 & 13.8 \\
Age & $31-40$ & 11 & 19.0 \\
& $41-50$ & 12 & 20.7 \\
& $51-60$ & 13 & 22.4 \\
& $>60$ & 14 & 24.1 \\
& Farmer & 17 & 29.3 \\
\multirow{5}{*}{ Occupation } & 15 & 25.9 \\
& Civil Servants & 3 & 5.2 \\
& Private Employees & 16 & 27.6 \\
& Self Employed & 7 & 12.1 \\
& Household & 17 & 29.3 \\
& Primary School & 12 & 20.7 \\
& Junior High School & 15 & 15.9 \\
& High School & 14 & 24.1 \\
\hline
\end{tabular}

that Minangkabau women are also included in taking risks in investing. The same result was obtained by Fitrimawati (2013) that the amount of Minangkabau women who invest in trading businesses are almost the same as men.

Younger people in Minangkabau are also interested in becoming investors in the business of cattle farm seduaan. Even people who are old (more than sixty years old) are still passionate about being involved in investing in cattle as a whole. In fact, the number of older people is higher when compared to all age levels. It happens because, at this age, parents are usually mature and have knowledge and experience in the cattle business as well. This is in accordance with the research of Grebel and Lytton (1998) and Tallo et al. (2015).

Occupation factors often determine a person's investment decision. In this study, the majority of investment work in seduaan cattle business is not a payday people but an entrepreneur including farmers and housewives. This result is the same as that stated by Barnewall (1987), some occupational groups, such as company executives, lawyers, doctors are more risk-averse in investing.
Tallo et al. (2015) found that investors who have jobs as civil servants are more likely towards the risk conservative, which is equal to 0.818 or $(81.8 \%)$ which the type of investment chosen does not have a high risk.

Someone's investment decision is related to the level of education because investment decisions are related to the courage to take risks. Bhandari and Deaves (2006) mention risk tolerance also have a relationship with one's education level. People who dare to take risks or risk aggressive can be said to be highly educated because they have extensive knowledge and are able to calculate the risks faced. In the results of this study, the education of investors is almost the same for each level of education. Mostly, their education is an elementary school, which is 29.3 percent. This is a bit not in accordance with the existing theory since this investment decision is in the field of animal husbandry. The majority of the animal husbandry sector is in the countryside. Many villagers are just elementary school graduates. This is the reason that attracts attention where rural people who have low education are still able to contribute to the development of the animal 
husbandry sector. It would be even better if highly educated people invest in real sectors like this farm.

\section{Profile of Investment in Cattle Farming Business with the Seduaan System}

The investment in cattle farm business can be said as a quite large business even though this investment is carried out by rural communities. Based on the results of the study, the highest amount of rupiah invested was in the amount of Rp. 10,000,000 to Rp. 20,000,000, which is around 36.2 percent. Investment of IDR $10,000,000$ and IDR 21,000,000 IDR 50,000,000 and IDR $51,000,000$ IDR $100,000,000$, it was $20 \%$ on average for each. Some investors invested more than $\mathrm{Rp} 100,000,000$ with the number of cattle invested were more than 10 (Table 2). They are kept by different breeders. This investor did not invest in one person because it is suspected that the farmer does not have the ability to maintain properly because of a shortage of labor and forage as feed. The other reason is they can share a relief to many relatives, because investors' investment decisions in this cattle seduaan business get profit, and also have the desire to help relatives who have a poor life. It is proved by seeing the results of research that the majority of them invest in relatives. Besides that, there are respondents who invest in neighbors and all the villagers. Some of them invest in their own children, but the percentage is very low.

\section{The Influence of Demographic Factors on Investment Decisions in Cattle Farming Business with The Seduaan System}

The investor decisions in choosing an investment type are influenced by several factors. The size of the investment related to demographic factors includes religion, age, gender, marital status, education, employment, income (Cahyadi, 2006). The results of the influence of demographic factors on investor's investment decisions in the business of people's cattle farm with the seduaan system are written below.

In Table 3 is seen that the factor that gives a significant and positive effect $(\mathrm{P}<\alpha$ 0.05 ) for investment decisions in the business of cattle farm seduaan is investors' education. It means that the education of investors greatly determines the size of the investment in the business of cattle farm seduaan. The higher the education of the investor is, the greater the investment will be and vice versa. As stated above, a person's investment decisions have a relationship with the level of education because investment decisions are related

Table 2. Profile of Investment in Cattle Farming Business with The Seduaan System

\begin{tabular}{llcc}
\hline Investment Profile & & Frequency (Person) & Percent (\%) \\
\hline & $<10,000,000$ & 11 & 19.0 \\
Total Investment & $10000000-20000000$ & 21 & 36.2 \\
(Rupiah) & $21,000,000-50,000,000$ & 12 & 20.7 \\
& $51,000,000-100,000,000$ & 10 & 17.2 \\
& $101,000,000-150,000,000$ & 1 & 1.7 \\
& $>150,000,000$ & 3 & 5.2 \\
\multirow{3}{*}{ Total investment } & $1-2$ & 36 & 62.1 \\
(Head) & $3-5$ & 11 & 19.0 \\
& $6-10$ & 8 & 13.8 \\
\multirow{3}{*}{ Investment Allocation } & 2 & 3.4 \\
(People) & $10-15$ & 1 & 1.7 \\
& $>15$ & 2 & 3.4 \\
& Children & 39 & 67.2 \\
& Relatives & 17 & 29.3 \\
\hline
\end{tabular}


Table 3. Results of Estimation of Demographic Factor on Investment Decisions

\begin{tabular}{|c|c|c|c|c|c|c|}
\hline \multirow{2}{*}{\multicolumn{2}{|c|}{ Model }} & \multicolumn{2}{|c|}{ Unstandardized Coefficients } & \multirow{2}{*}{$\begin{array}{l}\text { Standardized } \\
\text { Coefficients } \\
\text { Beta }\end{array}$} & \multirow[t]{2}{*}{$\mathrm{t}$} & \multirow[t]{2}{*}{ Sig. } \\
\hline & & $\mathrm{B}$ & Std. Error & & & \\
\hline \multirow{5}{*}{1} & (Constant) & $-3.236 \mathrm{E} 7$ & $4.210 \mathrm{E} 7$ & & -.769 & .446 \\
\hline & Xage & 411949.913 & 479444.367 & .133 & .859 & .394 \\
\hline & Xedu & $4.141 \mathrm{E} 6$ & $1.951 \mathrm{E} 6$ & .310 & 2.122 & $.038^{*}$ \\
\hline & Djob & $-3.061 \mathrm{E} 6$ & $1.193 \mathrm{E} 7$ & -.039 & -.257 & .798 \\
\hline & Dgender & $2.022 \mathrm{E} 7$ & $1.346 \mathrm{E} 7$ & .203 & 1,502 & .139 \\
\hline
\end{tabular}

* significant on $\alpha 0.05$

to the courage to take risks. Bhandari and Deaves (2006) mention risk tolerance also have a relationship with one's education level. People who dare to take risks (risk aggressive) can be said to be highly educated because they have extensive knowledge and are able to calculate the risks faced.

Age, occupation and gender factors did not significantly influence $(P>\alpha 0.05)$ on investment decisions in the business of cattle farm seduaan. It means that a young or old age does not affect the amount of investment. Likewise, for job factors, whether he works as an entrepreneur or a permanent employee does not determine the size of their investment. Moreover, gender does not affect the amount of their investment. Male invest as much as women's invest.

\section{CONCLUSION}

The business of cattle farm with seduaan system has contributed to the development of animal husbandry in West Sumatera. The people of West Sumatera have helped the government's task in realizing the independence and food security based on the social capital they have driven by the implementation of Minangkabau custom and culture. Their investment is large enough and it is done without a business agreement and only has the trust and desire to help relatives and villagers to live better lives. There are people who are low educated and some are highly educated, but from the results of research, the high and low education of investors affects the size of their investment. In short, whether they are male or female, being an employee or entrepreneur, young or old does not affect their investment.

\section{Suggestion}

1. With the increasing number of highly educated people, it is hoped that they will participate in this investment in cattle as much as possible so that the development of animal husbandry and food security can be realized in West Sumatera. It is also expected that this investment will be increased again for the younger generation. Therefore, a socialization program from the government is needed for the younger generation and educated people to be able to increase their participation in the people's animal husbandry business with seduaan system.

2. So far, the investment that is applied is based on social capital bonding and in the future will be developed in the form of bridging social capital, which is developed in groups such as cooperatives and other non-formal institutions.

3. Minangkabau is known as a migrant community. Beef Cattle farms with a profitsharing system need to be socialized to the migrant community from Minangkabau.

\section{REFERENCE}

Barnewall, M. M. 1987. Psychological Characteristics of the Individual 
Investor. In W. Droms, ed., Asset Allocation for the Individual Investor. Charlottesville, VA: The Institute of Chartered Financial Analyse.

Barber, B. and O. Terrance. 2001. "Boys Will Be Boys: Gender, Overconfidence, and Common Stock Investment". The Quarterly Journal of Economics: 261 292.

Bhandari, G. and Deaves, R. 2006. The Demographic of Overconfidence: The Journal of Behavioral Finance. Vol. 7. 1, 5-11.

Cahyadi, S. M. 2006. Effect of Demographic Factors on Investor Behavior and Type Investment. Perbanas Surabaya College of Economics.

Grable, J. E., and Lytton. R. H. 1998. Investor Risk Tolerance: Testing The Efficacy of Demographics As Differentiating and Classifying Factors.

Fatmawati., Rostin., dan Baso, J. N. 2016. Factors Affecting Demand for Beef in Indonesia. Economic Journal. Vol 1 (1) 128-134.

Fitrimawati., Berma, M., Shahadan, F., and Mohd. Fauzi. 2013. Kinship Social Capital and the Creation of Business Opportunities by Minangkabau Ethnics. Economic Journal Vol. 13 (1) 2-8.
Fitrimawati., Jafrinur, and Iskandar, I. 2018. Investment Decisions and Social Capital from. Ethnics Minangkabau in the People's Cattle Farming Business through The Benefit Sharing System. Cluster and Downstream National Seminar. Sustainable Research IV. Andalas University, Padang

Fuah, A. M., Petheram, J. and Priyanto, R. 2015. Evaluation of Farming System research FSr) on Small Livestock in West Timor of East Nusatenggara. Journal of Production Science and Animal Husbandry Technology Vol. 03(1): 12-20.

Kuncoro, M. 2003. Research Methods for Business \& Economics, How to Research \& Write Thesis: Airlanga Jakarta.

Said, S. 2017. The Role of Reproductive Technology in Supporting Effort Programs Special Efforts of Mandatory Cattle Breeding (in Indonesia: UPSUS SIWAB) for sustainable livestock. National Seminar on Animal Husbandry 3. University of Hanuddin, Makassar.

Tallo, R., Nanik L. and Gesti, M. 2015. Relationship Analysis of Demographic Factors, Risk Profiles and Investor Decisions in Asset Allocation. Finesta Vol.3 (2) 73 - 78. 